Article

\title{
Two New Phenolic Glycosides from Gnaphalium affine D. Don and Their Anti-Complementary Activity
}

\author{
Junli Li ${ }^{1,2}$, Doudou Huang ${ }^{1}$, Wansheng Chen ${ }^{3}$, Zhongxin Xi ${ }^{1}$, Cheng Chen ${ }^{1}$, Guanghui Huang ${ }^{1,2}$ \\ and Lianna Sun ${ }^{1, *}$
}

1 School of Pharmacy, Second Military Medical University, 325 Guohe Road, Shanghai 200433, China

2 Department of Pharmacy, Fujian University of Traditional Chinese Medicine, 1 Hutuo Road, Fuzhou 350108, China

3 Department of Pharmacy, Changzheng Hospital, Second Military Medical University, 415 Fengyang Road, Shanghai 200003, China

* Author to whom correspondence should be addressed; E-Mail: sssnmr@163.com or lnsun@smmu.edu.cn; Tel.: +86-21-8187-1308.

Received: 20 May 2013; in revised form: 25 June 2013 / Accepted: 25 June 2013 /

Published: 3 July 2013

\begin{abstract}
Two new phenolic glycosides, named gnaphaffine A and B (compounds 1 and 2), were isolated from Gnaphalium affine. together with six known compounds, including caffeic acid (3), everlastoside L (4), isorhamnetin-7- $O$ - $\beta$-D-glucopyranoside (5), quercetin3-O- $\beta$-D-glucopyranoside (6), scutellarein-7- $O$ - $\beta$-D-glucoside (7) and api-genin-7- $O$ - $\beta$-Dglucopyranoside (8). Their structures were elucidated by spectroscopic methods, including ESI-MS and 2D NMR spectroscopy (HMQC and HMBC). All compounds were evaluated for their anti-complementary activity on the classical pathway of the complement system in vitro.
\end{abstract}

Keywords: Gnaphalium affine; phenolic glycosides; anti-complementary activity

\section{Introduction}

The genus Gnaphalium belongs to the family Compositae and consists of approximately 200 species found all over the World, among which 19 are distributed in China [1]. Gnaphalium affine D. Don is an annual herbaceous plant, locally named Ching Ming vegetable in China. G. affine has been used as a traditional medicine for the relief of swelling, wounds, lumbago, angina ache in some Latin American countries [2]. Previous phytochemical investigation on Gnaphalium affine have reported the isolation of flavonoids [3-8], phenolic constituents [9], polysaccharides [10], essential oil compounds [11], 
diterpenes [12,13], and other chemical constituents [14]. Many of these components have been demonstrated to possess anti-complementary and antifeedant activities [2]. During our ongoing research to discover novel or bioactive constituents from $G$. affine, two novel phenolic glycosides were isolated from this plant, and named gnaphalium A (1) and B (2) (Figure 1).

Figure 1. Structures of compounds 1-8.
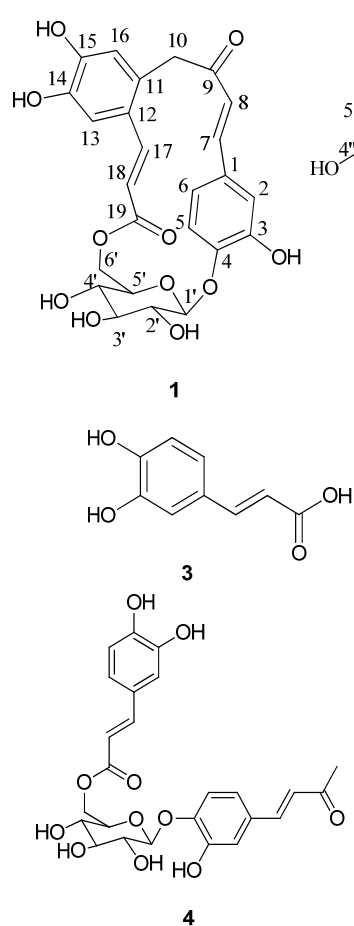

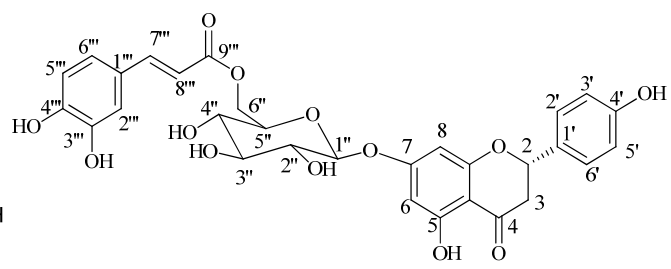

2<smiles>[R6]c1cc(O)c2c(=O)c([R2])c(-c3ccc(O)c([R])c3)oc2c1</smiles>

5: $\mathrm{R}_{1}=\mathrm{OMe}, \mathrm{R}_{2}=\mathrm{OH}, \mathrm{R}_{3}=$ glycopyranoside

6: $\mathrm{R}_{1}=\mathrm{OH}, \mathrm{R}_{2}=$ glycopyranoside, $\mathrm{R}_{3}=\mathrm{H}$

7: $\mathrm{R}_{1}=\mathrm{OMe}, \mathrm{R}_{2}=\mathrm{OH}, \mathrm{R}_{3}=$ glycopyranoside 8: $R_{1}=H, R_{2}=H, R_{3}=$ glycopyranoside

Besides, several known compounds were isolated and identified as caffeic acid (3) [15], everlastoside L

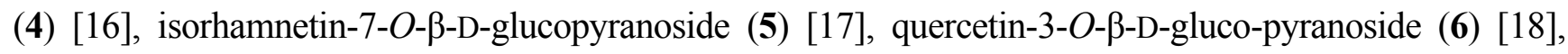
scutellarein-7-O- $\beta$-D-glucopyranoside (7) [19] and apigenin-7-O- $\beta$-D-gluco-pyranoside (8) [20], by comparison of their spectroscopic data with published values. Herein the isolation, characterization, and anti-complementary activity of these compounds were reported. In addition, a plausible biogenetic pathway for compound $\mathbf{1}$ has been proposed (Scheme 1).

Scheme 1. Plausible biogenetic pathway for compound 1.

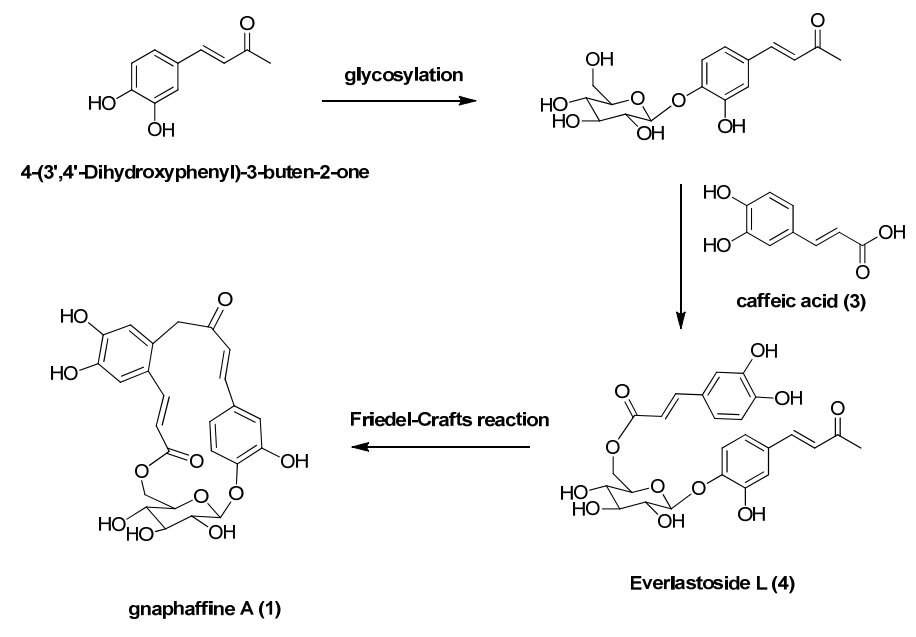




\section{Results and Discussion}

An $80 \%$ ethanolic extract of dried $G$. affine whole plant was suspended in distilled water and extracted with EtOAc. The EtOAc soluble fraction was concentrated under reduced pressure to produce a residue that was subjected multiple chromatography, two new compounds $\mathbf{1}$ and $\mathbf{2}$ and six known compounds 3-8 were isolated and identified.

Gnaphaffine A (1) was isolated as a yellow, amorphous powder. On the basis of a HR-ESI-MS peak at $m / z 501.1393[\mathrm{M}+\mathrm{H}]^{+}$and ${ }^{13} \mathrm{C}-\mathrm{NMR}$ data the molecular formula of $\mathbf{1}$ was determined to be $\mathrm{C}_{25} \mathrm{H}_{24} \mathrm{O}_{11}$, indicating 14 degrees of unsaturation. The IR spectrum showed the presence of hydroxyl (3535 $\left.\mathrm{cm}^{-1}\right)$, carbonyl $\left(1668 \mathrm{~cm}^{-1}\right)$ and benzene ring $\left(1606,1506 \mathrm{~cm}^{-1}\right)$ groups. The structure of the compound was established from detailed analysis of its ${ }^{1} \mathrm{H}$ - and ${ }^{13} \mathrm{C}-\mathrm{NMR}$ spectra, including 2D NMR. The ${ }^{13} \mathrm{C}$-NMR spectrum of $\mathbf{1}$ (Table 1), exhibited 25 signals that together with the information from a DEPT spectrum, indicated two methylene, fourteen methine, and nine quaternary carbons. Among these were one carbonyl group at $\delta 196.1$ (C-9) and one ester function at $\delta 166.1$ (C-19); as well as one anomeric methine at $\delta 100.7\left(\mathrm{C}-1^{\prime}\right)$ and four methines at $\delta 72.7\left(\mathrm{C}-2^{\prime}\right), 75.5\left(\mathrm{C}-3^{\prime}\right), 70.6\left(\mathrm{C}-4^{\prime}\right)$ and 73.7 $\left(\mathrm{C}-5^{\prime}\right)$, and one methylene at $\delta 65.2\left(\mathrm{C}-6^{\prime}\right)$, indicating the presence of a glucopyranose unit. Acid hydrolysis of 1 released D-glucopyranose, with an $[\alpha]_{\mathrm{D}}^{18}+38.2\left(c 0.15, \mathrm{H}_{2} \mathrm{O}\right)$. The glucopyranose moiety was determined to have a $\beta$-configuration at C-1' from the large coupling constant of $\mathrm{H}-1^{\prime}$ $(J=7.8 \mathrm{~Hz})$ [2]. The ${ }^{1} \mathrm{H}-\mathrm{NMR}$ spectrum (Table 1) displayed signals for an ABX spin system at $\delta 7.40$ $(1 \mathrm{H}, \mathrm{d}, J=1.8 \mathrm{~Hz}, \mathrm{H}-2), 7.08(1 \mathrm{H}, \mathrm{dd}, J=8.4,1.8 \mathrm{~Hz}, \mathrm{H}-6)$ and $6.80(1 \mathrm{H}, \mathrm{d}, J=8.4 \mathrm{~Hz}, \mathrm{H}-5)$; two trans-configured double bonds at $\delta 7.33(1 \mathrm{H}, \mathrm{d}, J=15.6 \mathrm{~Hz}, \mathrm{H}-7)$ and $\delta 6.90(1 \mathrm{H}, \mathrm{d}, J=15.6 \mathrm{~Hz}, \mathrm{H}-8)$, $\delta 8.02(1 \mathrm{H}, \mathrm{d}, J=15.6 \mathrm{~Hz}, \mathrm{H}-17)$ and $\delta 6.10(1 \mathrm{H}, \mathrm{d}, J=15.6 \mathrm{~Hz}, \mathrm{H}-18)$ which were further confirmed by the HMQC correlations (H-7/C-7, H-8/C-8, H-17/C-17 and H-18/C-18) and ${ }^{1} \mathrm{H}-{ }^{1} \mathrm{H}$ COSY (Figure 2) correlations $(\mathrm{H}-7 / \mathrm{H}-8$ and $\mathrm{H}-17 / \mathrm{H}-18)$; two singlet signals at $\delta 7.00(1 \mathrm{H}, \mathrm{s}, \mathrm{H}-13)$ and $\delta 6.75(1 \mathrm{H}, \mathrm{s}$, $\mathrm{H}-16)$ which suggests the presence of an 1,2,4,5-tetrasubstituted aromatic ring; one methylene group signals at $\delta 3.38(1 \mathrm{H}, \mathrm{m}, \mathrm{H}-10 \mathrm{a})$ and $\delta 4.26(1 \mathrm{H}, \mathrm{m}, \mathrm{H}-10 \mathrm{~b})$ showed a correlation with $\delta 44.3(\mathrm{C}-10)$ in the HMQC. In addition to the above signals, a sugar moiety was identified due to the distinct anomeric signal at $\delta 4.88\left(1 \mathrm{H}, \mathrm{d}, J=7.8 \mathrm{~Hz}, \mathrm{H}-1^{\prime}\right)$, four oxymethine protons signals between $\delta 4.10$ and $\delta 3.38$ and two oxymethylene protons signals at $\delta 4.38$ and $\delta 4.29$, which were further confirmed by the HMQC correlations and ${ }^{1} \mathrm{H}-{ }^{1} \mathrm{H}$ COSY correlations (Figure 2). Since the above-mentioned groups accounted for 13 degrees of unsaturation, the remaining degree suggested the presence of an additional ring system in the structure of $\mathbf{1}$. The HMBC experiment (Figure 2) showed clear correlations of ABX protons H-2 and $\mathrm{H}-6$ with $\mathrm{C}-7, \mathrm{H}-7$ with $\mathrm{C}-2$ and $\mathrm{C}-6$ and of $\mathrm{H}-8$ with $\mathrm{C}-1$, which confirmed the presence of the carbon-carbon double bond attached at C-1 of the ABX system, while correlations of $\mathrm{H}-7$ with $\mathrm{C}-9$ and of $\mathrm{H}-8$ with $\mathrm{C}-9$ and $\mathrm{C}-10$ confirmed the presence of the carbonyl group C-9 attached at C-8. Correlations of $\mathrm{H}-10 \mathrm{a}$ and $\mathrm{H}-10 \mathrm{~b}$ with $\mathrm{C}-9, \mathrm{C}-12(\delta$ 123.4) and C-16 $(\delta 117.9)$, and of $\mathrm{H}-16$ with C-10 confirmed the attachment of C-10 at carbonyl group (C-9) and C-11 of the tetrasubstituted aromatic ring at $\mathrm{C}-10$. 
Table 1. ${ }^{1} \mathrm{H}-\mathrm{NMR}(600 \mathrm{MHz})$ and ${ }^{13} \mathrm{C}-\mathrm{NMR}(150 \mathrm{MHz})$ data for compound 1 (DMSO- $d_{6}$, $\delta_{\mathrm{H}}$ in ppm, $J$ in $\left.\mathrm{Hz}\right)$.

\begin{tabular}{|c|c|c|}
\hline Position & $\boldsymbol{\delta} \mathbf{H}$ & $\delta \mathrm{C}$ \\
\hline 1 & - & 125.7 \\
\hline 2 & $7.40(\mathrm{~d}, 1.8)$ & 112.4 \\
\hline 3 & - & 145.6 \\
\hline 4 & - & 149.4 \\
\hline 5 & $6.80(\mathrm{~d}, 8.4)$ & 116.0 \\
\hline 6 & $7.08(\mathrm{dd}, 8.4,1.8)$ & 126.4 \\
\hline 7 & $7.33(\mathrm{~d}, 15.6)$ & 143.2 \\
\hline 8 & $6.90(\mathrm{~d}, 15.6)$ & 122.3 \\
\hline 9 & - & 196.1 \\
\hline $10 \mathrm{a}$ & $3.38(\mathrm{~m})$ & 142 \\
\hline $10 \mathrm{~b}$ & $4.26(\mathrm{~m})$ & 44.3 \\
\hline 11 & - & 127.5 \\
\hline 12 & - & 123.4 \\
\hline 13 & $7.00(\mathrm{~s})$ & 113.2 \\
\hline 14 & - & 144.8 \\
\hline 15 & - & 148.3 \\
\hline 16 & $6.75(\mathrm{~s})$ & 117.9 \\
\hline 17 & $8.02(\mathrm{~d}, 15.6)$ & 140.9 \\
\hline 18 & $6.10(\mathrm{~d}, 15.6)$ & 116.4 \\
\hline 19 & - & 166.1 \\
\hline $1^{\prime}$ & $4.88(\mathrm{~d}, 7.8)$ & 100.7 \\
\hline $2^{\prime}$ & $3.38(\mathrm{~m})$ & 72.7 \\
\hline $3^{\prime}$ & $3.38(\mathrm{~m})$ & 75.5 \\
\hline $4^{\prime}$ & $3.15(\mathrm{~m})$ & 70.6 \\
\hline $5^{\prime}$ & $4.10(t, 9.4)$ & 73.7 \\
\hline 6'a & $4.38(\mathrm{~d}, 11.4)$ & $65 ?$ \\
\hline $6^{\prime} \mathrm{b}$ & $4.29(\mathrm{~m})$ & 05.2 \\
\hline
\end{tabular}

Figure 2. Key ${ }^{1} \mathrm{H}-{ }^{1} \mathrm{H}$ COSY (bold lines) and $\mathrm{HMBC}(\mathrm{H} \rightarrow \mathrm{C})$ correlations of compounds $\mathbf{1}$ and 2.

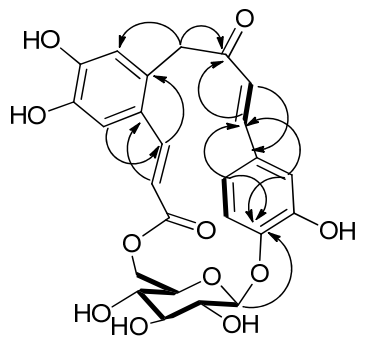

1

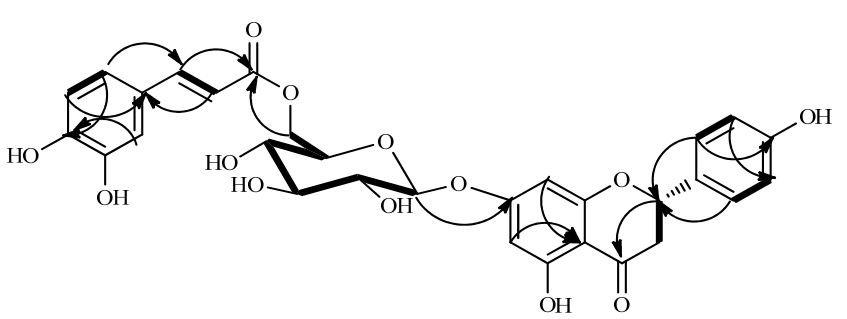

2

Another carbon-carbon double bond attached at C-12 was deduced from correlations of $\mathrm{H}-18$ with C-12, H-17 with C-11 $(\delta$ 127.5) and C-13 $(\delta$ 113.2) and of H-13 $(\delta$ 7.00) with C-17 $(\delta 140.9)$. In addition, correlations of $\mathrm{H}-17$ and $\mathrm{H}-18$ with $\mathrm{C}-19$ suggested the ester function was attached to C-18. The glucopyranose moiety was found to be attached at $\mathrm{C}-4$ as evidenced by the HMBC correlation from $\mathrm{H}-1$ ' to C-4 ( $\delta$ 149.4). Besides, the glucopyranose group was linked to C-19 through C-6' as determined by the HMBC correlations from H-6' ( $\delta 4.38$ and 4.29) to C-19. Based on this combined evidence, structure of compound $\mathbf{1}$ was confirmed as that of a novel phenolic glycoside that was trivially named gnaphaffine A. A plausible biogenetic pathway has been discussed for compound 1 herein (Scheme 1). Everlastoside L (4) was proposed as the precursor of compound 1 via Friedel-Crafts reaction. The 
common biological intermediate (4-(3',4'-Dihydroxyphenyl)-3-buten-2-one) [21] may convert into everlastoside L (4) via saccharification and esterification reactions.

Gnaphaffine B (2) was obtained as a pale yellow solid. Its molecular formula was determined as $\mathrm{C}_{30} \mathrm{H}_{28} \mathrm{O}_{13}$ by its HR-ESI-MS peak at $\mathrm{m} / z 597.1597$ [M-H] $]^{-}$(calcd for $\mathrm{C}_{30} \mathrm{H}_{29} \mathrm{O}_{13}, 597.1524$ ). IR absorptions suggested the presence of hydroxyl $\left(3455 \mathrm{~cm}^{-1}\right)$, carbonyl $\left(1692 \mathrm{~cm}^{-1}\right)$ and phenyl groups (1632, $1502 \mathrm{~cm}^{-1}$ ). The ${ }^{1} \mathrm{H}-\mathrm{NMR}$ spectrum of compound 2 showed three protons at $\delta 2.70$ (dd, $J=17.4,3.0 \mathrm{~Hz}), 3.26(\mathrm{dd}, J=12.0,17.4 \mathrm{~Hz})$ and $5.45(\mathrm{dd}, J=12.0,3.0 \mathrm{~Hz})$, typically assigned to $\mathrm{H}_{2}-3$ and $\mathrm{H}-2$ of a flavanol skeleton, an AA'XX' spin system at $\delta 7.27\left(2 \mathrm{H}, \mathrm{d}, J=8.4 \mathrm{~Hz}, \mathrm{H}-2^{\prime}, 6^{\prime}\right)$ and 6.76 $\left(2 \mathrm{H}, \mathrm{d}, J=8.4 \mathrm{~Hz}, \mathrm{H}-3^{\prime}, 5^{\prime}\right)$, and two meta-coupled protons at $\delta 6.18(1 \mathrm{H}$, brs, $\mathrm{H}-6)$ and $6.13(1 \mathrm{H}$, dd, $J=1.8,4.8 \mathrm{~Hz}, \mathrm{H}-8)$ and $5.45(1 \mathrm{H}, \mathrm{dd}, J=3.0,12.0 \mathrm{~Hz}, \mathrm{H}-2), 3.26(1 \mathrm{H}, \mathrm{dd}, J=12.0,17.4 \mathrm{~Hz}, \mathrm{H}-3 \mathrm{a}), 2.70$ $(1 \mathrm{H}, \mathrm{dd}, J=17.4,3.0 \mathrm{~Hz}, \mathrm{H}-3 \mathrm{~b})$, which suggested the presence of a $(S)$-Naringenin skeleton [22-24]; a sugar moiety due to the distinct anomeric signal at $\delta 5.05(1 \mathrm{H}, \mathrm{d}, 7.8 \mathrm{~Hz}, \mathrm{H}-1 ")$ and oxymethine protons in the rang $\delta 3.21-5.05$. The ${ }^{13} \mathrm{C}-\mathrm{NMR}$ data (Table 2) showed four methines at $\delta 69.6$ (C-4"), 73.9 (C-2"), 76.4 (C-3") and 77.1 (C-5"), one methylene at $\delta 63.2$ (C-6") and an anomeric methine at $\delta 99.3$ (C-1"), indicating the presence of a glucopyranose unit.

Table 2. ${ }^{1} \mathrm{H}-\mathrm{NMR}(600 \mathrm{MHz})$ and ${ }^{13} \mathrm{C}-\mathrm{NMR}(150 \mathrm{MHz})$ data for compound 2 (DMSO- $d_{6}$, $\delta_{\mathrm{H}}$ in ppm, $J$ in $\left.\mathrm{Hz}\right)$.

\begin{tabular}{|c|c|c|}
\hline Position & $\delta \mathbf{H}$ & $\delta \mathrm{C}$ \\
\hline 2 & $5.45(1 \mathrm{H}, \mathrm{dd}, 3.0,12.0)$ & 78.7 \\
\hline 3 & $\begin{array}{c}3.26(1 \mathrm{H}, \mathrm{dd}, 12.0,17.4) \\
2.70(1 \mathrm{H}, \mathrm{dd}, 17.4,3.0)\end{array}$ & 42.1 \\
\hline 4 & - & 197.1 \\
\hline 5 & - & 162.7 \\
\hline 6 & $6.18(1 \mathrm{H}, \mathrm{brs})$ & 96.3 \\
\hline 7 & - & 163.2 \\
\hline 8 & $6.13(1 \mathrm{H}, \mathrm{dd}, 1.8,4.8)$ & 95.5 \\
\hline 9 & - & 165.0 \\
\hline 10 & - & 103.3 \\
\hline $1^{\prime}$ & - & 128.6 \\
\hline $2^{\prime}, 6^{\prime}$ & $7.27(2 \mathrm{H}, \mathrm{d}, 8.4)$ & 12.4 \\
\hline $3^{\prime}, 5^{\prime}$ & $6.76(2 \mathrm{H}, \mathrm{d}, 8.4)$ & 115.2 \\
\hline $4^{\prime}$ & - & 157.8 \\
\hline $1^{\prime \prime}$ & $5.05(1 \mathrm{H}, \mathrm{d}, 7.8)$ & 99.3 \\
\hline $2^{\prime \prime}$ & $3.24(1 \mathrm{H}, \mathrm{m})$ & 73.79 \\
\hline $3 "$ & $3.30(1 \mathrm{H}, \mathrm{m})$ & 76.4 \\
\hline $4 "$ & $3.15(1 \mathrm{H}, \mathrm{m})$ & 69.6 \\
\hline $5^{\prime \prime}$ & $3.40(1 \mathrm{H}, \mathrm{m})$ & 77.1 \\
\hline $6^{\prime \prime}$ & $\begin{array}{c}4.42(1 \mathrm{H}, \mathrm{brd}, 12.0) \\
4.11(1 \mathrm{H}, \mathrm{dd}, 18.0,6.6)\end{array}$ & 63.2 \\
\hline $1 " '$ & - & 125.5 \\
\hline $2^{\prime \prime \prime}$ & $7.02(1 \mathrm{H}, \mathrm{d}, 4.2)$ & 114.9 \\
\hline $3^{\prime \prime \prime}$ & - & 145.6 \\
\hline $4^{\prime \prime \prime}$ & - & 148.4 \\
\hline $5 " '$ & $6.76(1 \mathrm{H}, \mathrm{d}, 8.4)$ & 115.7 \\
\hline 6"' & $6.94(1 \mathrm{H}, \mathrm{dd}, 8.4,2.4)$ & 121.2 \\
\hline $7^{\prime \prime \prime}$ & $6.24(1 \mathrm{H}, \mathrm{d}, 15.6)$ & 113.7 \\
\hline $8^{\prime \prime \prime}$ & $7.45(1 \mathrm{H}, \mathrm{d}, 15.6)$ & 145.3 \\
\hline 9"' & - & 166.4 \\
\hline
\end{tabular}


Acid hydrolysis of $\mathbf{2}$ yielded a free sugar that was identified as D-glucopyranose by measurement of the corresponding optical rotation $[\alpha]_{\mathrm{D}}^{18}+40.3$ (c $0.20, \mathrm{H}_{2} \mathrm{O}$ ). The glucopyranose moiety was determined to have a $\beta$-configuration at C-1" from the large coupling constant of $\mathrm{H}-1$ " $(J=7.8 \mathrm{~Hz})$ [2]. Furthermore, presence of a caffeoly moiety was confirmed by the detection of ABX spin system signals at $7.02\left(1 \mathrm{H}, \mathrm{d}, J=4.2 \mathrm{~Hz}, \mathrm{H}-2{ }^{\prime \prime}\right), 6.76\left(1 \mathrm{H}, \mathrm{d}, J=8.4 \mathrm{~Hz}, \mathrm{H}-5^{\prime \prime \prime}\right), 6.94$ (1H, dd, $\left.J=8.4,2.4 \mathrm{~Hz}, \mathrm{H}-66^{\prime \prime}\right)$, and the trans-configuration of the double bond was recognized by the large coupling constant $(J=15.6)$ observed for the olefinic resonances H-7"' and H-8"'. The glucopyranose attachment at C-7 was supported by the HMBC (Figure 2) correlation of H-1" (5.05) to C-7 (165.0). The glucopyranose group was linked to C-9"' through C-6"', as confirmed by the HMBC correlation from H-6" ( $\delta 4.42$ and 4.11$)$ to C-9"'. These suggested the glucopyranose group was linked to C-9"' through C-6". All proton and carbon signals were assigned via HMQC, HMBC (Figure 2) and ${ }^{1} \mathrm{H}-{ }^{1} \mathrm{H}$ COSY spectra. Therefore, compound 2 was identified as naringenin-7-O- $\beta$-D-(6"-E-caffeoyl)-glucopyranoside, and named gnaphaffine B.

Previous studies have already reported on the anti-complementary activity of components from G. affine [2,16]. Compounds $\mathbf{1}-\mathbf{8}$ were also evaluated in vitro for anti-complementary activity on the classical pathway of the complement. Heparin, with an $\mathrm{IC}_{50}$ value of $0.016 \mathrm{mg} / \mathrm{mL}$, was used as positive control in this study. Compounds 2, 3, 4 and 7 caused moderate inhibtion, showing $\mathrm{IC}_{50}$ values of 0.471 , $0.221,0.577$ and $1.041 \mathrm{mg} / \mathrm{mL}$, respectively. $\mathrm{IC}_{50}$ values for the remaing compounds $\mathbf{1 , 5}, \mathbf{6}$ and $\mathbf{8}$ were $69.63,81.50,23.01$, and $13.36 \mathrm{mg} / \mathrm{mL}$, respectively.

\section{Experimental}

\subsection{General}

Optical rotations were measured with Perkin-Elmer 341 polarimeter. UV and IR spectra were recorded on Shimadzu UV-2550 and Perkin-Elmer 577 (using $\mathrm{KBr}$ disks) spectrophotometers, respectively. NMR spectra were acquired on a Bruker Avance III spectrometer $\left(600 \mathrm{MHz}\right.$ for ${ }^{1} \mathrm{H}-\mathrm{NMR}$, $150 \mathrm{MHz}$ for ${ }^{13} \mathrm{C}-\mathrm{NMR}$, data in ppm relative to TMS). ESI-MS spectra were recorded on an Agilent 1200 series HPLC interfaced to an Agilent 6410 triple-quadrupole mass spectrometer equipped with an electrospray ionization source, and HR-ESI-MS spectra were recorded on an Agilent 1290 series HPLC interfaced to an Agilent 6538 UHD Accurate-Mass Q-TOF LC/MS (Agilent Corporation, Santa Clara, MA, USA). Semi-preparative RP-HPLC isolation was performed with an Agilent 1200 instrument with a refractive index detector (RID) using a YMC $5 \mu \mathrm{m} \mathrm{C8}$ column $(250 \mathrm{~mm} \times 10 \mathrm{~mm})$. Methanol for semi-preparative HPLC was of HPLC-grade (Merck, Darmstadt, Germany). Column chromatography: silica gel (200-300 mesh); macroporous adsorbing resin (D-101, ZTC-1, 0.3-1.2 mm, Tianjin Zhentiancheng Science \& Technology Co., Ltd., Tianjin, China); Sephadex LH-20 gel (40-70 $\mu \mathrm{m}$, Amersham Pharmacia Biotech AB, Uppsala, Sweden); silica gel H (Qingdao Haiyang Chemical Co. Ltd., Qingdao, China). All solvents for column chromatography and acid hydrolysis were of analytical grade (Shanghai Chemical Reagents Company, Ltd., Shanghai, China). Spots of compounds on TLC were developed using $10 \% \mathrm{H}_{2} \mathrm{SO}_{4}$-EtOH solution 


\subsection{Plant Material}

The whole G. affine plants were purchased at the Bozhou herbal market in Anhui Province, China, in July 2008 and identified by Prof. Wansheng Chen. A voucher specimen was deposited in the Department of Pharmacognosy, Second Military Medical University, Shanghai, China.

\subsection{Extraction and Isolation}

The dried, whole plant materials of $G$. affine $(2.7 \mathrm{~kg}$ ) were ground and extracted with $80 \% \mathrm{EtOH}$ three times $\left(25 \mathrm{~L}\right.$, each for $2 \mathrm{~h}$ ) under reflux at $70-80{ }^{\circ} \mathrm{C}$. Evaporation of the solvent at $60{ }^{\circ} \mathrm{C}$ yielded a crude extract (338 g), which was suspended in distilled water and successively partitioned with petroleum ether, ethyl acetate, and $n$-butanol. The ethyl acetate extract ( $60 \mathrm{~g}$ ) was fractionated by silica gel column chromatography (100-200 mesh, $720 \mathrm{~g})$, using a gradient of $\mathrm{CH}_{2} \mathrm{Cl}_{2}$ : $\mathrm{MeOH}(50: 1 \rightarrow 1: 1$; each $5 \mathrm{~L}, \mathrm{v} / \mathrm{v})$ to yield seven fractions $(\mathrm{A} \rightarrow \mathrm{G})$. Fraction $\mathrm{C}$ was chromatographed over a Sephadex LH-20 column eluted with a gradient of $\mathrm{MeOH}: \mathrm{H}_{2} \mathrm{O}(50: 50,80: 20,0: 100$, v/v) to give five combined sub-fractions $\left(\begin{array}{lll}\mathrm{C}_{1} & \mathrm{C}_{3}\end{array}\right)$. Fraction $\mathrm{C}_{1}$ was eluted on RP-18 gel column $\left(\mathrm{MeOH}: \mathrm{H}_{2} \mathrm{O}, 3: 7,5: 5,8: 2\right.$, v/v, each $500 \mathrm{ml})$ to obtain three parts $\left(\mathrm{C}_{1-1}-\mathrm{C}_{1-3}\right)$. Fraction $\mathrm{C}_{1-1}$ was further purified by Sephadex LH-20 CC with $\mathrm{MeOH}: \mathrm{H}_{2} \mathrm{O}(5: 5,8: 2, \mathrm{v} / \mathrm{v})$ to afford compounds $1(20 \mathrm{mg})$ and $2(28 \mathrm{mg})$. Fraction $\mathrm{C}_{1-2}$ was purified on a Sephadex LH-20 column (MeOH: $\mathrm{H}_{2} 0,3: 2$, v/v) and further subjected to RP-18 gel CC ( $\left.\mathrm{MeOH}: \mathrm{H}_{2} \mathrm{O}, 2: 3, \mathrm{v} / \mathrm{v}\right)$ to yield compound 3 (18 mg). Compounds 4 (25 mg) and 5 (18 mg) were obtained from fraction $\mathrm{C}_{1-3}$ using the same way as described for compound 3. Further purification of subfraction $\mathrm{C}_{2}$ by RP-18 gel CC (MeOH: $\mathrm{H}_{2} \mathrm{O}, 2: 3$; v/v) and Sephadex LH-20 CC (MeOH: $\mathrm{H}_{2} \mathrm{O}, 1: 1$; $\mathrm{v} / \mathrm{v})$ yielded compounds $6(17 \mathrm{mg})$ and $7(20 \mathrm{mg})$. Further purification of $\mathrm{C}_{3}$ by RP-18 gel CC (MeOH: $\left.\mathrm{H}_{2} \mathrm{O}, 8: 2 ; \mathrm{v} / \mathrm{v}\right)$ and Sephadex LH-20 CC $\left(\mathrm{CHCl}_{3}: \mathrm{MeOH}, 1: 1 ; \mathrm{v} / \mathrm{v}\right)$ yielded compound 8 (26 mg).

\subsection{Characterization of Compounds $\mathbf{1}$ and $\mathbf{2}$}

Compound 1. Yellow, amorphous powder; IR (KBr) $v_{\max } 3535,3414,1668,1591,1515,1288,1172$, $1077 \mathrm{~cm}^{-1}$; ${ }^{13} \mathrm{C}-\left(150 \mathrm{MHz}, \mathrm{DMSO}-d_{6}\right)$ and ${ }^{1} \mathrm{H}-\mathrm{NMR}\left(600 \mathrm{MHz}, \mathrm{DMSO}-d_{6}\right)$, see Table 1 and Supplementary Data; HR-ESI-MS: $m / z 501.1393[\mathrm{M}+\mathrm{H}]^{+}$(calcd for $\mathrm{C}_{25} \mathrm{H}_{24} \mathrm{O}_{11}, m / z$ 501.1391).

Compound 2. Pale yellow solid; IR (KBr) $v_{\max } 3856,3455,1787,1692,1632,1502,1274,1175$, $1085 \mathrm{~cm}^{-1}$; ${ }^{13} \mathrm{C}-\left(150 \mathrm{MHz}, \mathrm{DMSO}-d_{6}\right)$ and ${ }^{1} \mathrm{H}-\mathrm{NMR}\left(600 \mathrm{MHz}, \mathrm{DMSO}-d_{6}\right)$, see Table 2 and Supplementary Data; HR-ESI-MS: $m / z 597.1597$ [M-H] ${ }^{-}$(calcd for $\mathrm{C}_{30} \mathrm{H}_{29} \mathrm{O}_{13}, m / z$ 597.1524).

\subsection{Acid Hydrolysis of Compounds $\mathbf{1}$ and $\mathbf{2}$}

A solution of compound 1 (10 mg) or compound $2(10 \mathrm{mg})$ in $2 \mathrm{~N}$ aqueous $\mathrm{CF}_{3} \mathrm{COOH}(10 \mathrm{~mL})$ was refluxed at $80^{\circ} \mathrm{C}$ for $2 \mathrm{~h}$. The mixture was then diluted in water $(10 \mathrm{~mL})$ and extracted with EtOAc $(3 \times$ $3 \mathrm{~mL}$ ). The combined EtOAc layers were washed with $\mathrm{H}_{2} \mathrm{O}$ and evaporated to dryness to afford the glycoside. The residue was purified over an ODS column to afford D-glucopyranose (1.2 mg), which was identified on the basis of its specific rotation: $[\alpha]_{\mathrm{D}}^{18}+38.2\left(c 0.15, \mathrm{H}_{2} \mathrm{O}\right) ; 0.8 \mathrm{mg},[\alpha]_{\mathrm{D}}^{18}+40.3$ (c $\left.0.20, \mathrm{H}_{2} \mathrm{O}\right)$. 


\subsection{Anti-Complementary Activity Assay}

Based on Mayers' modified method, nornal human serum (NHS) obtained from healthy male donors (mean age 20 years) was used as the complement source, and it was treated with SRBC to remove the anti-sheep erythrocyte antibody. The NHS was diluted 1:10 with veronal-buffered saline $\left(\mathrm{VBS}^{2+}, \mathrm{PH}\right.$ 7.4, containing $0.5 \mathrm{mM} \mathrm{Mg}^{2+}$ and $0.15 \mathrm{mM} \mathrm{Ca}^{2+}$ ) and selected to give submaximallysis in the absence of complement inhibitors. Each saple was dissolved in $\mathrm{VBS}^{2+}$ with $1 \%$ dimethyl sulfoxide (DMSO). Heparin served as the positive control. The cells culture and biological activity assay were very similar to our previous study [25]. Optical density of the suupernatant was measured at $405 \mathrm{~nm}$ with a spectrophotometer.The inhition rate of haemolysis was calculated by the following formula: $\left[A-\left(A_{1}-A_{0}\right)\right] / A \times 100 \%$, where $A$ is the absorbance of $100 \%$ lysis; $A_{1}$ is the absorbance of the sample; and $A_{0}$ is the absorbance of control.

\section{Conclusions}

In conclusion, our phytochemical investigation of the roots extract of $G$. affine has identified two new phenolic glycosides, gnaphaffine A (1) and B (2), together with six known compounds, caffeic acid (3), everlastoside L (4), isorhamnetin-7-O- $\beta$-D-glucopyranoside (5), quercetin-3-O- $\beta$-Dglucopyranoside (6), scutellarein-7- $O$ - $\beta$-D-glucopyranoside (7) and apigenin-7- $O$ - $\beta$-D-glucopyranoside (8). A plausible biogenetic pathway has been proposed for compound 1 herein (Scheme. 1). The key precursor (4-(3',4'-Dihydroxyphenyl)-3-buten-2-one) may convert into key intermediate everlastoside L (4) via saccharification and esterification reactions. Cyclization of the everlastoside L (4) yielded compound 1, which was converted via Friedel-Crafts reaction. Anti-inflammatory activities for compounds 1-8 have been evaluated and compounds 2, 3, 4 and 7 exhibited significant in vitro anti-inflammatory activities through the classic anti-complementary pathway $\left(\mathrm{IC}_{50}\right.$ value $<10 \mathrm{mg} / \mathrm{mL}$ ).

\section{Acknowledgments}

This project was financially supported by a grant from the Science and Technology Commission of Shanghai Municipality (13ZR1448800). The authors thank Daofeng Chen (Department of Pharmacognosy, School of Pharmacy, Fudan University, China), and Zhihong Cheng (Department of Pharmacognosy, School of Pharmacy, Fudan University, China) for the biological activity evaluation of the isolated compounds. We are also grateful to Genjin Yang and Xin Dong (School of Pharmacy, Second Military Medical University, China) for the measurement of NMR and mass spectra.

\section{Conflict of Interest}

The authors declare no conflict of interest.

\section{References}

1. Qian, C.P.; Chen, H.Y. Flora reipublicae popularis sinicae. In Tomus 75 Anglospermae dicotyledonae Compositae (2); Lin, R., Ed.; Science Press: Beijing, China, 1959; Volume 26, pp. 221-242. 
2. Xi, Z.X.; Chen, W.S.; Wu, Z.J.; Wang, Y.; Zeng, P.Y.; Zhao, G.J.; Li, X.; Sun, L.N. Anti-complementary activity of flavonoids from Gnaphalium affine D. Don. Food Chem. 2012, $130,165-170$.

3. Aritomi, M.; Kawasaki, T. Dehydro-para-asebotin, a new chalconeglucoside in the flowers of Gnaphalium affine D. Don. Chem. Pharm. Bull. 1974, 22, 1800-1805.

4. Aritomi, M.; Shimojō, M.; Mazaki, T. Chemical Constituents in Flowers of Gnaphalium Affine D. Don. Yakugaku Zasshi 1964, 84, 895-896.

5. Morimoto, M.; Kumeda, S.; Komai, K. Insect Antifeedant Flavonoids from Gnaphalium affine D. Don. J. Agric. Food Chem. 2000, 48, 1888-1891.

6. Cuadra, P.; Harborne, J.B.; Waterman, P.G. Increases in surface flavonols and photosynthetic pigments in Gnaphalium luteo-album in response to UV-B radiation. Phytochemistry 1997, 45, 1377-1383.

7. Iwashina, T.; Kitajima, J.; Takemura, T. Flavonoids from the leaves of six Corylopsis species (Hamamelidaceae). Bio. System. Eco. 2012, 44, 361-363.

8. Torrengra, R.D.; Escarria, S.; Raffelsberger, B.; Achenbach, H. 5,7-dihydroxy-3,6,8trimethoxyflavone from the flowers of Gnaphalzum elegans. Phytochemistry 1980, 19, 2795-2796.

9. Shikov, A.N.; Kundracikova, M.; Palama, T.L.; Pozharitskaya, O.N.; Kosman, V. M.; Makarov, V.G.; Galambosi, B.; Kim, H.J.; Jang, Y.P.; Choi, Y.H.; et al. Phenolic constituents of Gnaphalium uliginosum L. Phytochemistry 2010, 3, 45-47.

10. Aoshima, Y.; Hasegawa, Y.; Hasegawa, S.; Nagasaka, A.; Kimura, T.; Hashimoto, S.; Torii, Y.; Tsukagoshi, N. Isolation of GnafC, a Polysaccharide Constituent of Gnaphalium affine, and Synergistic Effects of GnafC and Ascorbate on the Phenotypic Expression of Osteoblastic MC3T3-E1 Cells. Bios. Biotechnol. Biochem. 2003, 67, 2068.

11. Wei, C.Z.; Rui, X.Z.; Li, R.J.; Hong, G.; Yue, Z.; Qun, S. Chemical composition, antimicrobial and antioxidant activities of essential oil from Gnaphlium affine. Food Chem. Toxicol. 2011, 49, 1322.

12. Meragelman, T.L.; Silva, G.L.; Mongelli, E.; Gil, R.R. ent-Pimarane type diterpenes from Gnaphalium gaudichaudianum. Phytochemistry 2003, 62, 569-572.

13. Urzúa, A.; Torres, R.; Bueno, C.; Mendoza, L. Flavonoids and diterpenoids in the trichome resinous exudate from Pseudognaphalium cheiranthifolium, P. heterotrichium and P. vira vira Biochemical Systematics and Ecology 1995, 23, 459.

14. Xi, Z.X.; Wan, Y.; Zhao, G.J.; Li, X.; Wu, Z.J.; Sun, L.N. Chemical constituents of petroleum ether fractions of Gnaphalium affine D. Don. Acad. J. Sec. Mil. Med. Univ. 2011, 32, 311-313.

15. Wu, Z.J., Ouyang, M.A.; Yang, C.R. Polyphenolic constituents of Salvia sonchifolia. Acta Bot. Yunnan 1999, 21, 393-398

16. Morikawa, T.; Wang, L.B.; Ninomiya, K.; Nakamura, S.; Matsuda, H.; Muraoka, O.; Wu, L.J.; Yoshikawa, M. Eight New Glycosides, Everlastosides F-M, from the Flowers of Helichrysum arenarium. Chem. Pharm. Bull. 2009, 57, 853-859.

17. Xiang, Y.; Li, Y.B.; Zhang, J.; Li, P.; Yao, Y.Z. Studies on chemical constituents of Salsola collina. Zhongguo Zhong Yao Za Zhi 2007, 32, 409-413.

18. Zhou, Z.H.; Yang, C.R. Chemical Constituents of Crude Green Tea, the Material of Pu-er Tea in Yunnan. Acta Bot. Yunnanica 2000, 22, 343-350. 
19. Wang, L.B.; Toshio, M.; Gao, H.Y.; Huang, J.; Masayuki, Y.; Wu, L.J. Isolation and identification of chemical constituents of flavones from Flos Helichrysi Arenarii. J. Shengyang Pharm. Univ. 2009, 26, 792-795.

20. Calzada, F. Additional antiprotozoal constituents from Cuphea pinetorum, a plant used in Mayan traditional medicine to treat diarrhoea. Phytother. Res. 2005, 19, 725-727.

21. Zan, L.F.; Qin, J.C.; Zhang, Y.M.; Yao, Y.H.; Bao, H.Y.; Li, X. Antioxidan hipidin derivatives from medicinal mushroom Inonotus hispidus. Chem. Pharm. Bull. 2011, 59, 770-772.

22. Helle, T.O.; Gary, I.S.; Johannes, V.S.; Søren, B.C.; Anna, K.J. Isolation of the MAO-inhibitor naringenin from Mentha aquatica L. J. Ethnopharmacol. 2008, 117, 500-502.

23. Li, X.C.; Joshi, A.S.; Tan, B.; Elsohly, H.N.; Walker, L.A. Zjawiony, J.K., Ferreira, D. Absolute configuration, conformation, and chiral properties of flavanone-(3-8")-flavone biflavonoids from Rheedia acuminate. Tetrahedron 2002, 58, 8709-8717.

24. Liu, Y.M.; Yang, J.S.; Liu, Q.H. Chemical constituents research from Carthamus tinctorius L. J. Chin. Med. Mater. 2005, 28, 289.

25. Zhu, H.W.; Di, H.Y.; Zhang, Y.Y.; Zhang, J.W.; Chen, D.F. A protein-bound polysaccharide from the stem bark of Eucommia ulmoides and its anti-complementary effect. Carbohydr. Res. 2009, 344, 1319-1324.

Sample Availability: Samples of the compounds 1-8 are available from the authors.

(C) 2013 by the authors; licensee MDPI, Basel, Switzerland. This article is an open access article distributed under the terms and conditions of the Creative Commons Attribution license (http://creativecommons.org/licenses/by/3.0/). 